\title{
FAKTOR-FAKTOR YANG MEMPENGARUHI KEBERHASILAN PROGRAM PEMBERDAYAAN MASYARAKAT MISKIN DI KECAMATAN POLONGBANGKENG UTARA KABUPATEN TAKALAR PROPINSI SULAWESI SELATAN
}

\author{
Dahyar Daraba \\ Dosen IPDN Kampus Sulawesi Selatan \\ E-mail:dahyardaraba66@gmail.com
}

\begin{abstract}
ABSTRAK, Penelitian ini bertujuan untuk menganalisis faktor-faktor yang berpengaruh terhadap tingkat keberhasilan program pemberdayaan masyarakat miskin oleh para pihak (stakeholders) melalui dana Bantuan Langsung Pemberdayaan Sosial (BLPS) di Kecamatan Polongbangkeng Utara Kabupaten Takalar. Penelitian ini menggunakan pendekatan kuantitatif. Populasi penelitian ini adalah pengurus kelompok usaha bersama (KUBE) yang terdiri atas 75 orang. Dari jumlah populasi tersebut diambil sampel sebanyak 63 orang dengan teknik random sampling. Pengumpulan data dilakukan dengan teknik kuisioner, wawancara, dan dokumentasi. Data dianalisis dengan teknik analisis statistik deskriptif dengan menggunakan persentase, sedangkan pengujian hipotesis penelitian menggunakan uji F dan uji $\mathrm{t}$ yang diolah dengan program SPSS versi 16. Hasil penelitian menjelaskan bahwa tingkat keberhasilan program pemberdayaan masyarakat miskin berada pada kategori baik (47,62\%). Hasil uji $\mathrm{F}($ sig $=0.000<0.05)$ menunjukkan bahwa variabel komunikasi, sumber daya, disposisi, dan struktur birokrasi secara bersama-sama mempunyai pengaruh yang positif terhadap keberhasilan program pemberdayaan masyarakat miskin dengan kontribusi sebesar $34,1 \%$. Secara parsial variabel komunikasi, sumber daya, disposisi, dan struktur birokrasi juga berpengaruh positif terhadap keberhasilan program pemberdayaan masyarakat miskin.
\end{abstract}

Kata Kunci: komunikasi, sumber daya, disposisi, struktur birokrasi.

\section{FACTORS AFFECTING THE SUCCESS EMPOWERMENT PROGRAM OF THE POOR IN THE DISTRICT OF NORTH POLONGBANGKENG DISTRICT TAKALAR SOUTH SULAWESI PROVINCE}

ABSTRACT This study aimed to analyze the factors that affect the success rate of empowerment of the poor by the parties (stakeholders) through Social Empowerment Direct Assistance (BLPS) in the District of North Polongbangkeng Takalar. This study uses a quantitative approach. The population of this study is the management group together (KUBE) which consists of 75 people. Of the population of as many as 63 samples taken by random sampling technique. The data collection was done by using questionnaires, interviews, and documentation. Data were analyzed with descriptive statistical analysis techniques using percentages, while the research hypothesis testing using the F test and $t$ test were processed with SPSS version 16. The results explained that the level of success of community development projects that are in the good category $(47.62 \%)$. F-test $($ sig $=0.000<0.05)$ indicates that the variable communication, resources, disposition, and bureaucratic structures together have a positive influence on the success of community development projects with a contribution of $34.1 \%$. In partial communication, resources, disposition, and bureaucratic structures also a positive influence on the success of community development projects.

Key words: communication, resources, disposition, bureaucratic structure.

\section{PENDAHULUAN}

Kemiskinan merupakan masalah sosial yang dihadapi dan menjadi perhatian banyak orang di dunia. Kemiskinan lazimnya dilukiskan sebagai kurangnya pendapatan untuk memenuhi kebutuhan hidup yang pokok. Dikatakan berada di bawah garis kemiskinan apabila pendapatan tidak cukup untuk memenuhi kebutuhan hidup yang paling pokok seperti pangan, pakaian tempat berteduh dan lain-lain (Salim, 1982:37). Tolok ukur kemiskinan yang lain menurut Sajogyo (1977) adalah: (1) tidak memiliki faktor produksi sendiri seperti, tanah, modal, dan keterampilan, (2) tidak memiliki kemungkinan untuk memiliki aset produksi dengan kekuatan sendiri, (3) tingkat pendidikan mereka rendah dan kebanyakan membantu orang tua dalam memenuhi kebutuhan hidupnya sehari-hari, (4) kebanyakan tinggal di desa sebagai pekerja bebas dan berusaha, (5) banyak yang tinggal di kota berusia muda dan tidak memiliki keterampilan.
Berdasarkan tolok ukur kemiskinan yang dikemukakan di atas, Dinas Sosial Kebudayaan dan Pariwisata Kabupaten Takalar mengadakan pendataan yang hasilnya menunjukkan bahwa penduduk miskin di Kabupaten Takalar tahun 2008 sebanyak 19.948 orang, dan tahun 2009 sebanyak 16.416 orang. Meskipun terjadi penurunan jumlah penduduk miskin, namun hal itu belum bisa menggembirakan karena jumlah penduduk miskin tahun 2009 masih memerlukan perhatian dan upaya dari pemerintah melalui program nyata dalam menanggulangi kemiskinan sebagaimana dikemukakan oleh Ginanjar (1996) tentang perlunya program khusus bagi masyarakat yang kurang berdaya.

Kabupaten Takalar, mendapat program Bantuan Langsung Pemberdayaan Sosial (BLPS) pada pertengahan tahun 2008. Program ini dilaksanakan di sepuluh kelurahan/desa pada dua kecamatan yaitu Polongbangkeng Utara dan Galesong Selatan yang meliputi 50 Kelompok Usaha Bersama 
(KUBE). Program ini didesain dalam bentuk kelompok guna meningkatkan interaksi antaranggota kelompok, antarkelompok dengan kelompok, serta antarkelompok dengan pemerintah. Dengan terjadinya interaksi multi arah diharapkan terjadi proses pembelajaran yang optimal sebagaimana dikemukakan oleh Mardikanto (2013: 248) bahwa proses pembangunan adalah proses interaksi semua pihak untuk memperbaiki mutu hidup masyarakat. Setiap kelompok usaha mendapatkan bantuan dana sebesar Rp. 30.000.000, dan bantuan teknis dari pemerintah berupa pendampingan masyarakat. Program pemberdayaan masyarakat ini dapat berhasil jika didukung oleh komunikasi yang berlangsung dua arah antara pemberi bantuan dan penerima bantuan. Asumsinya adalah masyarakat perlu diminta untuk secara sukarela mengkomunikasikan apa-apa yang menjadi kebutuhannya. Selain itu, sebaik apapun program yang ditawarkan jika proses komunikasi tidak lancar maka dapat berakibat pada lancarnya proses kegiatan pemberdayaan yang dilakukan. Faktor pendukung lainnya adalah sumber daya manusia dengan asumsi bahwa pengetahuan, sikap, dan keterampilan yang dimiliki serta nilai-nilai yang dianut oleh para stakeholders kegiatan akan berdampak kepada keberhasilan program. Hal ini didukung oleh pendapat Edward III, G.C; ( 2007 : 66-69) bahwa faktor-faktor yang berpengaruh terhadap program pemberdayaan masyarakat adalah komunikasi (communication), sumber daya (resources), disposisi (disposition), dan struktur birokrasi

Ada tiga indikator yang dapat dipakai dalam mengukur keberhasilan variabel komunikasi yaitu: Transmisi, penyaluran komunikasi yang baik akan dapat menghasilkan suatu implementsi yang baik pula. Sering kali yang terjadi dalam penyaluran komunikasi adalah adanya salah pengertian (miskomunikasi), hal tersebut disebabkan oleh komunikasi yang telah melalui beberapa tingkatan birokrasi, sehingga apa yang diharapkan terdistori di tengah jalan. Kejelasan, komunikasi yang diterima oleh para pelaksana kebijakan (street-level-bureaucrats) harus jelas dan tidak membingungkan (tidak ambigu/ mendua). Ketidakjelasan pesan kebijakan tidak selalu menghalangi implementasi, tetapi pada tataran tertentu, para pelaksana membutuhkan fleksibilitas dalam melaksanakan kebijakan. Pada tataran yang lain, hal tersebut justru akan menyelewengkan tujuan yang hendak dicapai oleh kebijakan yang telah diterapkan. Konsistensi, perintah yang diberikan dalam pelaksanaan suatu komunikasi harus konsisten dan jelas (untuk diterapkan atau dijalankan). Karena jika perintah yang diberikan sering berubahubah, maka dapat menimbulkan kebingungan bagi pelaksana di lapangan.

Selain itu, yang mempengaruhi kaberhasilan implementasi kebijakan adalah sumberdaya manusia. Kebutuhan untuk profesionalisme sumber daya manusia dan aktivitas yang mereka lakukan dapat memberikan kontribusi pada suksesnya usaha dan dapat memberikan daya saing perusahaan/organisasi atas produktivitas, kualitas dan jasa pelayanan. (Robert, 2001:1). Olehnya itu, pembudayaan pendidikan guna meningkatkan kemampuan sumber daya manusia sangat diperlukan (Tjokroamidjoyo, 2004:46). Selanjutnya, yang memengaruhi keberhasilan implementasi suatu program adalah disposisi (disposition). Disposisi atau sikap dan pelaksanaan kebijakan adalah faktor penting ketiga suatu kebijakan publik. Hubbeis, et.al. (2008:14) mengatakan bahwa cara seseorang pemimpin dalam memberdayakan bawahannya adalah pemimpin mempercayai bawahannya untuk bisa melakukan lebih banyak karena potensi yang dimilikinya. Menurut Mortimer (2002:178) mengatakan cara mendorong orang atau bawahan adalah jangan rendahkan seorang bawahan, jangan kritik bawahan di depan umum, beri perhatian penuh pada bawahan, dan selalu terbuka pada hal-hal kecil. Makmur (2009:175-176) kelangsungan hidup sebuah organisasi berkaitan erat dengan proses perilaku manusianya yang dapat memperkuat roh atau jiwa bagi kedinamisan sebuah struktur organisasi.

Berdasarkan uraian tersebut di atas, maka penelitian ini bertujuan menganalisis tingkat keberhasilan dan faktor-faktor yang berpengaruh terhadap program pemberdayaan masyarakat miskin oleh para pihak (stakeholders) melalui dana Bantuan Langsung Pemberdayaan Sosial (BLPS) di Kecamatan Polongbangkeng Utara Kabupaten Takalar Propinsi Sulawesi Selatan.

\section{METODE}

Disain penelitian ini merupakan penelitian korelasional, yang bertujuan untuk mengkaji faktorfaktor yang mempengaruhi tingkat keberhasilan program pemberdayaan masyarakat melalui bantuan langsung pemberdayaan sosial. variabel penelitian ini adalah komunikasi $\left(\mathrm{X}_{1}\right)$, sumberdaya $\left(\mathrm{X}_{2}\right)$, disposisi $\left(\mathrm{X}_{3}\right)$, dan struktur birokrasi $\left(\mathrm{X}_{4}\right)$ sebagai variabel independen, serta tingkat keberhasilan pogram pemberdayaan masyarakat miskin(Y) sebagai variabel dependen. Indikator dari variabel komunikasi adalah transmisi, kejelasan, dan konsistensi informasi. Untuk variabel sumberdaya indikatornya adalah penguasaan teknik/cara, kualitas layanan bimbingan, dan ketersediaan sarana dan prasana pendukung kegiatan; Sementara untuk disposisi, indikatornya adalah pengambilan keputusan mengutamakan kepentingan peserta KUBE dan adanya pengawasan dari instansi terkait seperti Dinas Sosial dan Kepala Desa/Lurah. Indikator dari variabel strukrur birokrasi adalah terdapatnya Standard Operating Prosedures (SOP) dan pelaksanaan pragmentasi (penyebaran tanggungjawab). Selanjutnya, indikator tingkat keberhasilan usaha adalah terdapatnya kemajuan usaha, kelangsungan usaha dan kemandirian para anggota kelompok usaha bersama (KUBE).

Sumber data dari Dinas Sosial sebanyak 2 orang, Lurah/Kepala Desa 2 orang dan pengurus Kelompok Usaha Bersama (KUBE) sebanyak 63 orang yang 
diambil 75 orang pengurus secara acak sederhana. Dengan demikian jumlah sumber data keseluruhan sebanyak 67 orang. Pengumpulan data dilakukan dengan teknik kuisioner (angket), wawancara, dan telaah dokumen. Angket adalah pengumpulan data yang berupa daftar pernyataan terkait dengan pokok permasalahan dengan mengacu pada sub variabel penelitian. Angket disusun menggunakan skala Likert dengan lima alternatif jawaban. Telaah dokumen yaitu digunakan untuk mencari keterangan atau pengumpulan data sekunder yang berkaitan dengan pokok permasalahan mengenai pemberdayaan masyarakat miskin. Sedangkan untuk teknik wawancara digunakan untuk mengumpulkan data terkait pelaksanaan program pemberdayaan masyarakat miskin dengan sumber data dari para pelaksana program pemberdayaan masyarakat miskin pada Kantor Dinas Sosial Kabupaten Takalar dan Kepala Desa/Lurah. Data dianalisis dengan teknik analisis statistik deskriptif dengan menggunakan persentase, sedangkan pengujian hipotesis penelitian menggunakan uji $\mathrm{F}$ dan uji t dengan program SPSS.

Lokasi penelitian ini bertempat di Kecamatan Polombangkeng Utara Kabupaten Takalar Propinsi Sulawesi Selatan.

\section{HASIL DAN PEMBAHASAN}

Aspek-aspek yang diselidiki dalam penelitian ini adalah tingkat keberhasilan program pemberdayaan masyarakat miskin dan faktor-faktor yang mempengaruhi keberhasilan pelaksanaan program pemberdayaan masyarakat miskin yang terdiri dari komunikasi, sumber daya, disposisi, dan struktur birokrasi. Oleh karena itu, variabel penelitian ini adalah komunikasi, sumber daya, disposisi, dan struktur birokrasi sebagai variabel independen, dan tingkat keberhasilan pogram pemberdayaan masyarakat miskin sebagai variabel dependen.

Definisi operasional variabel penelitian ini adalah: (i) komunikasi (communication) yang dimaksud adalah kemampuan para stakeholders menyalurkan informasi yang jelas dan konsisten dalam rangka pelaksanaan program pemberdayaan masyarakat miskin melalui Bantuan Langsung Pemberdayaan Sosial di Kecamatan Polongbangkeng Utara Kabupaten Takalar, Propinsi Sulawesi Selatan, (ii) sumber daya (resources) yang dimaksud adalah kemampuan untuk mengelola kelompok usaha bersama (KUBE) dan usaha ekonomi produktif (UEP) dengan segala sumber daya yang tersedia, (iii) disposisi (disposition) yang dimaksud adalah sikap pemimpin/pendamping kegiatan/instansi terkait dalam menggerakkan/memanfaatkan sumber daya yang ada, (iv) struktur birokrasi (bureaucratic structure) yang dimaksud adalah kemampuan pelaksana untuk mengelola/menjalankan kegiatan sesuai dengan bidang tugas, dan (v) tingkat keberhasilan program pemberdayaan masyarakat miskin adalah kemajuan usaha dan kemandirian masyarakat miskin yang mendapat bantuan setelah mengikuti program pemberdayaan.
Secara umum program pemberdayaan masyarakat miskin di Kecamatan Polongbangkeng Utara Kabupaten Takalar tingkat keberhasilannya sesuai jawaban responden berada dalam kategori baik (47,62\%), namun ada $19,05 \%$ yang hanya berada pada kategori cukup. Hal ini terjadi karena cenderung kepengurusan kelompok usaha bersama (KUBE) tidak berjalan sebagaimana yang diharapkan. Kerjasama antara anggota di kelompok usaha ada yang tidak berjalan. Mereka cenderung bekerja secara sendirisendiri, interaksi antaranggota dalam satu kelompok tidak intensif, apalagi interaksi antarkelompok usaha ekonomi produktif tidak berjalan dengan lancar, padahal seperti yang diakui oleh Mardikanto (2013) bahwa proses pembangunan adalah interaksi semua pihak untuk memperbaiki mutu hidup. Tukar informasi,keterampilan dan pengetahuan antaranggota KUBE tidak berjalan secara optimal, sehingga ketika menjumpai permasalahan sulit untuk mereka selesaikan dengan baik.

Hasil penelitian menunjukkan bahwa ada sekitar $33 \%$ responden memberikan respon/jawaban berada dalam kategori sangat baik. Hal ini terutama mereka yang masuk kelompok usaha pertukangan. Usaha meubel ini memang sudah lama digemari oleh masyarakat terutama di masyarakat di kelurahan Manongkoki Kecamatan Polongbangkeng Utara Kabupaten Takalar. Usaha pertukangan dapat dikatakan berkembang sangat luas. Daerah pemasaran tidak hanya secara lokal di Kabupaten Takalar sendiri, tetapi juga telah dipasarkan keluar wilayah Takalar terutama ke kabupaten tetangga seperti Kabupaten Gowa dan Kabupaten Jeneponto Propinsi Sulawesi Selatan. Namun demikian jika dilihat dari komsumen yang memakai hasil produk meubel tersebut, mereka lebih banyak anggota masyarakat golongan ekonomi menengah ke bawah. Ini terjadi karena kualitas dari produk meubel seperti lemari, meja makan, kursi, dan lain-lain belum dapat menyamai produk dari hasil ukiran Jepara.

Jika usaha ekonomi produktif jenis pertukangan dapat dikatakan mengalami perkembangan, lain halnya dengan usaha percetakan. Jenis usaha ini dapat dikatakan kurang berhasil. Penyebabnya adalah karena hasil dari usaha percetakan tidak jelas pemasarannya. Usaha ini hanya berjalan ketika terjadi musim pesta perkawinan atau pesta lainnya yang banyak memesan untuk dicetakkan undangan. Untuk cetakan jenis yang lain misalnya kartu nama atau sablon baju, kecenderungan masyarakat di Takalar langsung memesan di Kota Makassar. Sehingga jenis usaha percetakan tersebut tidak berhasil sebagaimana yang diharapkan. Sementara itu, untuk usaha pertukangan terus mengalami perkembangan. Sebanyak $85 \%$ dari kelompok usaha ekonomi produktif jenis pertukangan mampu mandiri dan terus mengembangkan usahanya, walaupun tidak lagi mendapat suntingan modal dari pemerintah.

Jenis usaha ekonomi produktif lainnya yang dapat dianggap berhasil adalah usaha batu merah dan menjahit. Usaha batu merah mempunyai tingkat 
resiko gagal yang kecil. Dengan bermodalkan tanah liat yang ada di sekitar rumah mereka usaha ini dapat berjalan. Yang sulit kadang-kadang ditemui oleh kelompok usaha bersama batu merah ini adalah sumber bahan bakar yang berasal dari kayu. Selain harganya mahal juga sulit diperoleh. Tetapi permintaan batu merah yang banyak dilakukan oleh masyarakat maka usaha tersebut dapat berkembang. Demikian juga usaha menjahit, dengan modal keterampilan yang telah mereka miliki atas bimbingan dari pendamping kegiatan, maka mereka dapat mengembangkan usahanya. Ini menjelaskan bahwa keterampilan yang dimiliki oleh pendamping kegiatan dapat ditransmisikan dengan baik terutama kepada jenis usaha penjahitan dan pertukangan. Demikian juga kejelasan dan konsistensi informasi yang disampaikan oleh pendamping kegiatan kepada kelompok usaha penjahitan dan pertukangan dapat berjalan dengan baik. Ini menunjukkan bahwa komunikasi dari para pendamping kegiatan menentukan keberhasilan program pemberdayaan. Fakta ini juga menjelaskan bahwa komunikasi yang diperoleh para anggota kelompok usaha tidak mengalami distorsi di tengah jalan walaupun isi dari komunikasi tersebut telah melalui beberapa tingkatan birokrasi seperti dinas sosial ke pendamping kegiatan dan selanjutnya ke anggota kelompok usaha bersama (KUBE).

Keberhasilan beberapa kelompok usaha sebagaimana dielaborasikan di atas, juga dipengaruhi oleh penguasaan teknik atau cara mengelola pemberdayaan dari para pendamping kegiatan, kualitas layanan bimbingan yang diberikan kepada para anggota KUBE, termasuk dukungan sarana dan prasarana yang tersedia. Kebutuhan untuk profesional dari para pendamping untuk setiap aktivitas yang mereka lakukan dapat memberikan konstribusi pada suksesnya usaha. Profesionalisme para pendamping kegiatan dan ketua KUBE dapat memberikan daya saing organisasi atas produktivitas, kualitas dan jasa pelayanan.

Peranan ketua KUBE dalam mengelola jenis usaha produktif yang dilaksanakan memberikan konstribusi yang berarti terhadap kemajuan usaha dari setiap kelompok. Karena itu, keberhasilan suatu program tidak hanya tergantung pada kualifikasi pemberdayaan masyarakat saja, tetapi juga sangat tergantung kepada kondisi faktor-faktor lain, misalnya mengenai "key individual" dalam struktur kekuasaan dari masyarakat penerima manfaat. Individu-individu yang masuk dalam "key individual" ini adalah mereka tokohtokoh informal seperti misalnya pemuka agama, petani kaya, atau pedagang kaya. Kaitannya dengan penelitian ini adalah bahwa ketika ketua kelompok ingin dibentuk maka yang perlu mendapat perhatian adalah mereka yang tergolong dalam kelompok "key individual" ini. Selain itu, disposisi atau sikap dari para stakeholders juga turut mendukung keberhasilan program. Sikap para stakeholders yang terus berupaya meningkatkan kemampuan para anggota kelompok usaha dan terus melakukan pengawasan terhadap keberlangsungan kegiatan usaha ekonomi produktif juga menjadi faktor penting dari keberhasilan program kegiatan di setiap kelompok usaha. Demikian juga untuk variabel struktur birokrasi, dimana dengan ketersediaan Standard Operating Prosedures (SOP) maka tugas-tugas dan fungsi mereka menjadi jelas, baik terhadap pendamping kegiatan, instansi terkait seperti Dinas Sosial/Kepala desa/Lurah, para anggota dan Ketua KUBE. Hal ini juga ditunjang oleh adanya fragmentasi tanggungjawab dari para stakeholders. Dengan adanya penyebaran tanggung jawab menjelaskan bahwa para stakeholders memberikan kewenangan kepada anggota KUBE untuk melakukan lebih banyak atas potensi yang dimilikinya.

Dalam kepengurusan KUBE perlu mendapat perhatian adalah anggota KUBE itu sendiri terutama dalam hal kemampuannya untuk bekerja bersama, kemampuan mereka untuk bermitra pengusaha atau dengan instansi terkait. Keberhasilan suatu program pemberdayaan masyarakat, pada dasarnya ditentukan oleh partisipasi masyarakat, baik dalam pemberian input, pelaksanaan, pemantauan, dan evaluasi, termasuk pemanfaatan hasil-hasil atau produk dari pemberdayaan itu sendiri. Karena itu, peran aktif dari semua anggota KUBE sebagai penerima manfaat sangat menentukan keberhasilan program.

Hasil penelitian ini mendukung pendapat Edward III, G.C (2007), bahwa ada empat faktor yang mendukung keberhasilan program pemberdayaan masyarakat yaitu komunikasi (communication), sumber daya (resources), disposisi (disposition), dan struktur birokrasi (bureaucratic structure).

\section{SIMPULAN}

Tingkatkeberhasilanprogrampemberdayaanmasyarakat miskin berada dalam kategori sangat baik sebesar 33,33 persen, kategori baik sebanyak 47,62 persen, dan sisanya 19,05 persen dalam kategori cukup. Komunikasi, sumber daya, disposisi, dan struktur birokrasi secara bersama-sama berpengaruh positif terhadap tingkat keberhasilan program pemberdayaan masyarakat miskin yang ditunjukkan dengan nilai $\operatorname{sig}=0,000$ pada derajat signifikansi sebesar 5 persen. Demikian pula secara parsial variabel komunikasi, sumber daya, disposisi dan struktur birokrasi memberikan pengaruh positif terhadap keberhasilan program. Besarnya pengaruh variabel independen tersebut ditunjukkan oleh koefisien regresi yaitu variabel komunikasi sebesar 0,471 ; sumber daya $=0,149$; disposisi sebesar 0,220 ; dan struktur birokrasi sebesar 0,044 .

\section{DAFTAR PUSTAKA}

Edward III. G.C. 2007. Jurnal Administrasi Negara. LAN. Jakarta.

Ginanjar,K.1996. Pemberdayaan Masyarakat: Sebuah Tinjauan Administrasi. Buletin Alumni SESPA. Edisi IV. Jakarta.

Hubeis, M, Najib, M, (2008), Manajemen Strategik Dalam Pengembangan Daya Saing Organisasi, PT Gramedia, Jakarta. 
Makmur, 2009 Teori Manajemen Stratejik dalam Pemerintahan dan Pembangunan, PT Refika Aditama.

Mardikanto, T. 2013. Pemberdayaan Masyarakat dalam Perspektif Kebijakan Publik, Penerbit Alfabeta, Bandung.

Mortimer. R. 2002. Psikologi yang Efektif untuk Manajer, Mitra Utama Jakarta.

Robert, L M. 2001. Manajemen Sumber Daya Manusia, Salemba Empat.
Sajogyo, 1977. Golongan Miskin dan Partisipasi dalam Pembangunan Desa. dalam Prisma, 6 (3) . Maret. LP3ES: Jakarta.

Salim, Emil. 1982, Perencanaan Pembangunan dan Pemerataan Pendapatan, Yayasan Idayu; Jakarta.

STjokroamidjoyo, 2004. Penyelenggaraan Good Governance dan Perwujudan Masyarakat Madani, LAN. Jakarta. 